\title{
Intellectual Property Protection of Pelargoniums
}

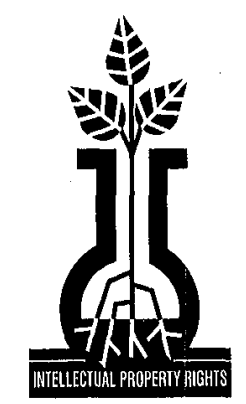

Richard Craig ${ }^{1}$

Additional index words. plant patents, breeders' rights, Plant Variety Protection Act, geranium

Summary. Pelargoniums represent a major floricultural crop in international markets. Intellectual property protection in the form of U.S. plant patents (200 since 1980) and European breeders' rights have been used for asexually propagated Pelargoniun. In addition, the hundreds of F', hybrid seed-reproduced cultivars are protected as trade secrets. International protection through the International Union for the Protection of New Varieties of Plants (UPOV) and the use of utility patents will accelerate breeding efforts; however, issues such as "essentially derived" and the farmer and research exemptions still must be resolved.

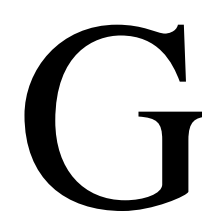

enetic improvement of Pelargonium has been conducted since the 1600s, when the first species were transported from South Africa to Europe by the Dutch East India Company. Pelargonium peltatum (ivy leaf geranium) was cultivated in Europe prior to 1700 , and the major ancestral species of $P$. $\times$ domesticum L. H. Bailey (regal Pelargonium) were known in Holland as early as 1687. Pelargonium inquinans, a primary ancestor of $P . \times$ hortorum L. H. Bailey (zonal geranium) was cultivated in Europe prior to the end of the 18th century (DeMarie, 1991). Thus, almost 200 years before the research of Johann Gregor Mendel, plant breeders were involved in hybridization and selection of Pelargonium spp. for their beauty in both conservatories and gardens. 
The first use of intellectual property protection in the United States for Pelargonium was in 1940, when 'Fiat Queen', a zonal geranium, was patented (PP355) by Charles A. Brown II of Hinsdale, Ill. Since 1940, 214 Pelargonium cultivars have been patented in the United States (Table 1), and at least as many seed-reproduced $F_{1}$ hybrid cultivars have been introduced and the parental lines have been protected as trade secrets. Most of the breeding activity has occurred since 1980, a time when numerous sexually and asexually reproduced cultivars have been introduced by commercial and academic breeders for use in commercial floriculture.

For a discussion of European breeders' rights for Pelargonium, one should refer to the Proc. of the Third International Geranium Conference, published late in 1993. Also, a complete list of all patented cultivars (through Oct. 1991) is included in Geraniums IV( Craig, 1992).

I attempt to present here a rationale for breeders' rights, to delineate the various methods of intellectual property protection for Pelargonium, to relate plant breeding research with breeders' rights, to discuss some practical aspects of breeders' rights, and finally, to discuss the current status of IPR and to list several issues that will affect breeders' rights in the 1990s.

\section{Rationale for breeders' rights}

"Intellectual property" is a legal term referring to ideas, concepts, and inventions that may receive a form of governmental statutory protection (i.e., patent, trademark, trade secret, etc.) of the inventor/breeders' rights. The term is used in contrast to the legal concept of "real property," which refers to tangible (real) objects such as land, cattle, buildings, machines, etc. In a nonlegal context, intellectual property best describes a new plant cultivar-"intellectual" referring to the creativity involved in plant breeding and "property" to indicate that it is the personal property of the plant breeder or of the organization that is licensed to propagate it.

Breeders' rights is a concept (and a law in $\approx 26$ countries) recognizing that the breeder of a specific cultivar (intellectual property) has guaranteed rights under the law and that these rights are protected through statutes and judicial processes.

Protection ofintellectual properties dates back to 200 BC in Greece. However, the first official legislation related to the subject occurred in 1474 in the City State of Venice. Incidentally, one of the first people to benefit from this legislation was Galileo, who had invented a machine for irrigating land. More recently, the "Universal Declaration of Human
Rights" of the United Nations included the following statement: "Everyone has the right to protection of the moral and material interests resulting from any scientific, literary or artistic production of which he is the author."

In essence, intellectual property protection is a simple contract between an inventor and the federal government. If an inventor discloses the details of his invention to the public so that this information can be used to further scientific development, then the federal government will grant the inventor a time-limited monopoly on the use and sale of the invention.

A landmark legal decision was Diamond v. Chakrabarty, which says, "Congress intended statutory subject matter to include anything under the sun that is made by man." This decision relates to plant material and animal material as well as inert material (Diamond v. Chakrabarty, 1980). It can apply to the patenting of plants and/or animals because it is possible to "make" new plants and animals using recombinant DNA techniques or conventional breeding techniques.

\section{Protection mechanisms}

New cultivars of plants and novel processes by which plants are propagated or produced are considered to be intellectual properties. As intellectual properties, they can be protected by:

-Plant Patents-asexually reproduced cultivars

-Plant Variety Protection Certificates-sexually reproduced inbreds and cultivars

-General Patents (Utility Patents)-plant cultivars and processes

-Trade Secrets-plant cultivars and processes

Some attorneys are even suggesting other novel approaches for protecting plant cultivars, such as design patents and copyrights.

\section{Plant patents (Sec. 161 patents)}

The Townsend-Purnell Act of 1930 specifically provides protection for plant cultivars that are reproduced asexually (Congress of the United States, 1930). The inventor of a new asexually propagated plant is required only to describe the plant to the best of his/her ability. This requirement is different from the general patent procedures, which require rather detailed documentation. There have been about 8300 plant patents allowed for such plants in the past 63 years.
D rotection of properties dates back to $200 \mathrm{BC}$ in Greece.
Table 1. Number of patented Pelargoniums since 1930.

\begin{tabular}{lc}
\hline Date & Number \\
\hline $1930-1939$ & 0 \\
$1940-1949$ & 8 \\
$1950-1959$ & 0 \\
$1960-1969$ & 2 \\
$1970-1979$ & 14 \\
1980-1989 & 102 \\
1 Jan. 1990-29 June 1993 & 88 \\
\hline
\end{tabular}


Not only does

patent law

protect against

the unlicensed

sale, use, or

reproduction of

the invention, but also covers the

parts and the embodied idea.
In the congressional hearings that occurred prior to the passage of the Plant Patent Act, those who argued for the act wanted to give plant breeders the same status that inventors of chemical and mechanical processes have through patent laws. It was stated that, "The purpose of the bill is to afford agriculture, so far as practicable, the same opportunity to participate in the benefits of the patent system as has been given industry and thus assist in placing agriculture on a basis of economic equality with industry. The bill will remove the existing discrimination between plant developers and industrial inventors." It was hoped that the bill would afford a sound basis for investing capital in plant breeding and, consequently, stimulate plant development through private funds.

During his lifetime, Luther Burbank had supported this viewpoint: "A man can patent a mouse trap or copyright a nasty song, but if he gives to the world a new fruit that will add millions to the value of earth's annual harvests, he will be fortunate if he is rewarded by so much as having his name connected with the result."

Thomas Edison is quoted as saying at the congressional hearing "Nothing that Congress could do to help farming would be of greater value and permanence than to give the plant breeder the same status as the mechanical and chemical inventor now have through the patent law. There are but few plant breeders. This (bill) will, I feel sure, give us many Burbanks."

\section{Plant variety protection}

Another congressional act ofimportance to plant breeders is the Plant Variety Protection Act of 1970, which provided protection for inbred plant cultivars produced from seed (Congress of the United States, 1970). This act includes both a "farmers" exemption and a research exemption. A sample of protected seeds must be deposited in the National Seed Laboratory at Fort Collins, Colo.; 3116 cultivars have been protected as of Sept. 1991$68.6 \%$ in the agronomic group, $4.5 \%$ flower seeds, and $26.9 \%$ vegetable seeds (statistics were provided by the National Seed Laboratory and the Plant Variety Protection Office, based on the Progress Rpt. of Sept. 1991). Certificates have been issued in 83 crops; no geranium cultivars have been protected under this act.

The definitions and rules of construction set forth in the Plant Variety Protection Act indicate that the term "novel variety" may be represented by, without limitation, seed, transplants, and plants, and is satisfied if there is:

1) Distinctness in the sense that the variety clearly differs by one or more identifiable morphological, physiological, or other characteristics (which may include those evidenced by processing or product characteristics; for example, milling and baking characteristics in the case of wheat) as to which a difference in genealogy may contribute evidence, from all prior varieties of public knowledge at the date of determination within the provisions of section 42 ; and

2) Uniformity in the sense that any variations are describable, predictable, and commercially acceptable; and

3) Stability in the sense that the variety, when sexually reproduced or reconstituted, will remain unchanged with regard to its essential and distinctive characteristics with a reasonable degree of reliability commensurate with that ofvarieties of the same category in which the same breeding method is employed.

\section{Utility patents (Sec. 101 patents)}

General patents (legally called utility patents) are identical to those given for other inventions for more than 200 years. The first use of utility patents for plants per se has occurred recently. Utility patents were granted more than 30 years ago for plant methods and processes. Not only does the general patent law protect against the unlicensed sale, use, or reproduction of the invention, but also covers the parts and the embodied idea. Implied is the right of the inventor to license the rights for the use or sale of the patented product in return for royalties to be paid to the inventor and/or organization that employs the inventor.

To be patentable, an invention must exhibit:

-Utility-usefulness.

-Novelty---no prior use, publication, or sale; there is a 1-year limit in the United States, but none for foreign patents.

-Nonobviousness-would not be obvious to a person skilled in the art (of plant breeding).

At least one utility patent has been allowed for Pelargoniums-- U.S. Patent No. 4,897,957 Precision Flowering of Regal Pelargoniums (Pelargonium $\times$ domesticum); the inventors are J.R. Oglevee and R. Craig. General patents are applicable for cultivars per se, and processes and other products resulting from biotechnological and conventional breeding manipulations; a recent bibliography has been assembled on this topic (U.S. Dept. of Agriculture, 1992).

\section{Protection of geranium cultivars}

Virtually all asexually propagated cultivars of Pelargonium that are available from 
clean stock programs are patented (Sec. 161 patents); these include zonals, ivies, and regals. The criteria for plant patenting-new and distinct, nonobviousness, prior asexual propagation-provide a broad base for geranium improvement. Similar criteria would apply to general patents.

Distinct infers that the new cultivar has characteristics that clearly distinguish it from existing cultivars. During the past several years, f-lower color and patterning, leaf color, and greenhouse/garden performance have dominated the patent scene. In the future, such traits as host-plant resistance, interspecific hybrids, postproduction characteristics, and stress-related tolerances will receive more attention. "New" implies that it has not been commercialized; there is a 1-year limit. Nonobviousness is not well-defined in the case of plant patents, but is that portion of patent law "that requires an inventive step"an improvement over prior art. Cultivars resulting from a planned breeding program would seem to satisfy the requirement of nonobviousness, while plants developed from clonal selection or as spontaneous sports or mutations would require greater inspection.

I believe that all improved cultivars will be patented in the future. Seed-reproduced cultivars usually are not protected because they are $\mathrm{F}_{1}$ hybrids; parental inbreds that are cross-pollmated to produce $F_{1}$ hybrid cultivars are protected as trade secrets, although they can also be protected by all other available mechanisms.

Most cultivars are protected on an international basis; this is generally accomplished through various breeders' rights legislation. International Union for the Protection of New Varieties of Plants (UPOV) is the international agreement responsible for protecting breeders' rights.

Plant breeding must be viewed as a business that operates like other businesses. There are creative employees, facilities, equipment, taxes, etc. Unlike many other horticultural businesses, plant breeding requires a long time for product development.

A breeding program might not result in a commercial product for 8 to 20 years; however, investment of funds and time must be made continually. The return on the breeder's investment is realized when the first cultivars are commercialized. Without royalty or license fees, no breeder would risk this financial investment. In addition, legal costs for intellectual property protection must be considered. The amount of royalty for cultivars of floricultural plants are crop-dependent. A current estimate for zonal geraniums is $\$ 0.02 /$ unit.

A typical scenario for a program vis-a-vis investments and returns would be:
Assume: 8 years of investment into the breeding program without any financial returns. Assume: that only $\$ 250,000$ is invested per year for employees, facilities, equipment, interest.

Assume: that royalties are $\$ 0.02$ per propagule or $\$ 20,000$ per million units.

Assume: that 10 patented commercial cultivars are developed in the program.

Total investment: $\$ 2,000,000$

The number of propagants that must be sold to return investment costs without profit, and excluding interest on the investment that otherwise might be received, would be $100,000,000$ units or 10 million of each cultivar over the commercial life of the cultivar (which may be as short as 5 years).

One might argue that sports can be discovered and patented and their cost is minuscule vs. development through a breeding program. An example of a geranium cultivar that originated as a "sport" is 'Danielle' (sport of 'Veronica'). This is a fact, and sports (mutations) ofpatented cultivars are usually controlled in licensing agreements for this reason. A sport, spontaneous or induced, usually results from a simple genetic change; note that the tens of thousands of other genes remain unaltered and were due to the creative genius of the plant breeder. This fact alone speaks to the current interest in "essentially derived" cultivars. One caveat-the discoverer of the sport is usually the inventor (plant patent) for legal purposes; however, ownership may be in question if the inventor of the original cultivar fails by license agreement to reserve an interest in any sport(s) that may be selected.

\section{Documentation}

A novel plant cultivar must have distinct, uniform, and stable characteristics created and/ or incorporated by the inventor. Thus, novelty must include more than simple morphological descriptions. A full-color photograph is required; the photograph is usually made by a professional photographer because color must match the descriptions-usually color chartsreferenced in the patent document.

Plant breeders currently use visual descriptions; however, plant "fingerprinting" by way of chromosome counts, chemical composition, machine identification of color by reflectance-absorption methods, light and electron microscopy of morphological or anatomical features, chromosome structure, and genetic descriptions are modern methods that can be used to document the novel nature of the invention.

"Fingerprinting" will be more sophisticated in the future; we are now in the era of
D lant breedviewed as a business that operates like other businesses. 


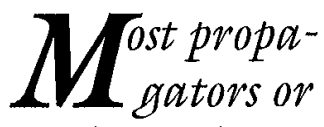
producers know the legal boundaries with respect to propagation; however, some are unaware that propagation for any reason-whether for their own use, trials, or sale-is considered infringement. molecular genetics and the use of recombinant DNA and DNA-restriction enzymes. The DNA sequence determines protein structure and, ultimately, the biochemical profile (fingerprint) of living organisms. Techniques such as restriction fragment length polymorphism (RFLP) and random amplified polymorphic DNA (RAPD) protocols provide exquisite detail of differences in plant cultivars. The data are obtained at the DNA level, and thus are unaffected by the environment and are not subject to the time of gene expression (i.e., plants can be identified at any stage ofdevelopment). Published research on Pelargoniums has been conducted primarily with chloroplast DNA (Krecji and Galbraith, 1987; Metzlaff et al., 1981; Palmer et al., 1987); however, other studies with nuclear DNA are in progress at several institutions. Documentation might also include biochemical markers such as specific enzymes, isozyme patterns (Tokumasu et al., 1977; Yu, 1985), plant pigments (Asen and Griesbach, 1983; Fujioka et al., 1991), amino acids, and other specific biochemical compounds (Bauer and Treutter, 1990a; 1990b; Harney, 1966; Walters et al., 1990) that might be present in detectable quantities or specific combinations that are characteristic of the novel plant. Sophisticated documentation can be used in the patent description; however, it is even more important to have this information in infringement cases.

\section{What is infringement?}

Sexual propagation (covered by the Plant Variety Protection Act) or asexual reproduction (covered by the Townsend-Purcell Act) of a protected cultivar for any purpose without a license is an infringement of the inventor's rights. Although exemptions are recognized in the Plant Variety Protection Act for research and for farmers, it is not implicit in either the Plant Patent Legislation or for plants protected by a general patent. Burden of proof that someone has infringed a novel plant cultivar patent is with the patent holder. Plant patent infringement is simply stated to include three prohibitions: Asexual reproduction, selling, and/or using the plant so reproduced. Protected (patented) geraniums are the property of the inventor, who often assigns propagation rights to a primary propagator. In a sense, the inventor or his/her parent company is really licensing mother plants to a propagator for the production of cuttings or propagules. It is this act oflicensing that speaks to the payment of royalties for each propagule produced. The primary propagator may also have the right to sub-license certain propagation rights to secondary propagators.

Licenses are legal contracts and include several important stipulations-among these are provisions for the enforcement and collection of royalties, a protocol for the handling of sports (mutations), and requirements for the proper labeling of plants.

The flower grower who purchases propagules from a licensed propagator has the responsibility not to propagate patented plants (unless a license has been granted) and to attach an identifying label to each plant that is marketed. Royalties are usually paid to the propagator when cuttings are purchased and thus the producer has already satisfied this part of the law.

Failure to pay royalties stipulated in the license agreement is against the law and is a financial affront to the inventor; it is really no different than stealing or illegally converting his/her property.

Most propagators or producers know the legal boundaries with respect to propagation; however, some are unaware that propagation for any reason-whether for their own use, trials, or sale-is considered infringement.

\section{Making the decision to patent a cultivar}

I get dozens of questions each year from growers, avocational horticulturists, and commercial corporations about protecting novel plants that they have created or discovered. They often believe that the novel plant will be of interest to a commercial propagator or seed company.

These are the questions that I normally ask:

-What are the genus and species of the plant?

-What is the origin of their invention or discovery?

-How is the plant uniformly reproducedby seed or by asexual propagation such as cuttings, grafts, or divisions?

-If a sport; what was the parent cultivar and was it protected?

-Why do they believe that the new cultivar has commercial potential? What competition exists in the industry?

-Are they willing to spend the money and time to pursue intellectual property protection? tion:

I then give them the following informa-

-A list of attorneys who specialize in the intellectual property protection of plants and/or plant related processes.

-The names of commercial companies involved in the propagation and/or breeding of the crop.

-Names of experts who may assist them in documenting characteristics of the novel plant or process.

- References to published information on intellectual property protection. 
The decision to protect intellectual properties will develop from consultation with an attorney. However, inventors' rights are invalidated if more than 1 year elapses between public disclosure of a cultivar and patent application. For foreign utility (general) patent rights to be obtained, it is important that there is no public disclosure prior to filing the application. Several tips for the plant inventor or discoverer are:

-Maintain excellent records of the invention. Records should be dated and signed. Photodocument the invention.

-Maintain tight control over the invention. Do not share it with anyone without a valid testing license (an attorney can develop a testing license for the inventor's use). Do not sell propagules or plants of the invention. If you are patenting a process, do not discuss your ideas with anyone without a signed confidentiality agreement.

- Prepare a disclosure document in consultation with an attorney as early as possible. Use a prior (recently issued) patent or certificate for the crop as a model.

-Propagate the invention to ensure that it is propagable and uniform. This is a requirement of the plant patent legislation.

\section{Current status}

There is a high level of activity with respect to intellectual property protection of plants. This activity is occurring both at the national and international levels. Nationally, issues include the choice of protection mechanisms-a current trend is toward the use of a general patent for plants instead of traditional plant patents or plant variety protection legislation. While costs are greater and time for processing may be longer, most experts believe that the scope of protection may be enhanced.

On an international level, several concerns are evident. One concern is the status of the International Union for the Protection of New Varieties of Plants (UPOV) with respect to its adoption by current and future member nations. Many legal and ethical questions need to be resolved regarding international transport of patented cultivars; these involve plants imported into a country where the patent has been allowed and also when patented cultivars are exported to any country that does not have equitable reciprocal protection laws and practices.

Additional information on intellectual property issues was presented in a ASHS Colloquium: The Horticultural DilemmaTrademarks, Patents, Royalties, and Cultivars (Darke, 1991; Elliott, 1991; Hutton, 1991; Rogers, 1991).

\section{Significant issues for the 1990s}

-Further movement toward the internationalization ofintellectual property protection.

-The protection of new cultivars with general patents rather than continued use of the plant patent or plant variety protection certificate.

-Increased litigation both nationally and internationally; particularly with respect to "pirated" plants exported into the United States and the European Economic Community. -Protection of plant parts and a redefinition of research exemptions.

-Legislative or judicial interpretations of the concepts of "minimum distance" and "essentially derived" with respect to plant intellectual properties.

\section{Literature Cited}

Asen, S. and R. Griesbach. 1983. High pressure liquid chromatographic analysis of flavonoids in geranium florets as an adjunct for cultivar identification. J. Amer. Soc. Hort. Sci. 108(5):845-850.

Bauer H. and D. Treutter. 1990a. Identification of Pelargonium genotypes by phenolic fingerprints. I. Separation and identification of phenolic compounds in leaves. Gartenbauwissenschaft 55(3):113-118.

Bauer, H. and D. Treutter. 1990b. Identification of Pelargonium genotypes by phenolic fingerprints. II. Cultivar identification by HPLC analysis of leafphenols combined with discriminant analysis. Gartenbauwissenschaft 55(4):187-191.

Congress of the United States, House Committee on Patents. 1930. Plant Patents. Hearings before the Committee, 9 Apr. 1930. U.S. Government Printing Office, Washington, D.C.

Congress of the United States, House Committee on Agriculture. 1970. Plant Variety Protection Act. U.S. Government Printing Office, Washington, D.C. House Rpt. No. 91-1605.

Craig, R. 1992. Intellectual property protection, p. 389-404. In: J.W. White (ed.). Geraniums IV. Ball,, Geneva, Ill.

Darke, R. 1991. A curator's viewpoint. HortScience 26(4):362-363.

DeMarie, E.T. 1991. Studies of in vitro propagation of geophytic and xerophytic Pelargonium species and hybrids. PhD Diss. Cornell Univ., Ithaca, N.Y.

Diamond v. Chakrabarty. 1980. U.S. Reports 477: 303-322.

Elliott, W.H., Jr. 1991. Property rights and plant germplasm. HortScience 26(4):364-365.

Fujioka, M., M. Kato, F. Kakihara, and S. Tokumasu. 1991. Anthocyanidin composition of petals in Pelargonium $\times$ domesticum Bailey. J. Jpn. Soc. Hort. Sci. 59(4):823-832.

Harney, P.M. 1966. A chromatographic study of

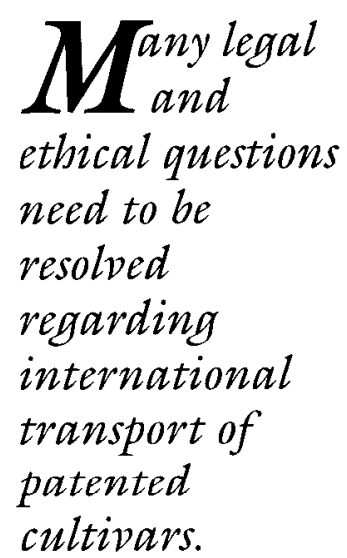


species presumed ancestral to Pelargonium $\times$ hortorum Bailey. Can. J. Genet. Cytol. 8:780787.

Hutton, R.J. 1991. New funds for plant breeding. HortScience 26(4):361-362.

Krecji, A. and D. Galbraith. 1987. Characterization of chloroplast DNA isolated from variegated cultivars of Pelargonium zonale. Plant Physiol. 83(Suppl. 4):14.

Metzlaff, M., T. Borner, and R. Hagemann. 1981. Variations of chloroplast DNAs in the genus Pelargonium and their biparental inheritance. Theor. \&Applied Genet. 60(1):37-41.

Palmer, J.D., J.M. Nugent, and L.A. Herbon. 1987. Unusual structure of geranium chloroplast DNA: A triple sized inverted repeat, extensive gene duplications, multiple inversions and two repeat families. Proc. Natl. Acad. Sci. USA 84(3):769-773.
Rogers, O.M. 1991. Germplasm and how to protect it. HortScience 26(4):360-361.

Tokomasu, S., F. Yano, and M. Kato. 1977. Estimation of genetic relationships among Pelargonium species by the electrophoretic patterns of isozymes. Jpn. J. Genet. 52(3):197-205.

U.S. Dept. of Agriculture. 1992. Biotechnology: Patenting issues-Jan. 1979-Mar. 1992. Natl. Agr. Library, Beltsville, Md.

Walters, D.S., R. Craig, and R.O. Mumma. 1990. Heritable trichome exudate differences of resistant and susceptible geraniums, p. 317-327. In: J.E. Casida (ed.). Pesticides and alternatives. Elsevier, New York.

$Y u, S .1985$. Untersuchungen zur interspezifischen kompatibilitat und biosystematik bei der gattung Pelargonium. Thesis. Fak. Landw. U. Gartenb. Techn. Universitat Munchen Weihenstephen. 